UDK: 613.72Yoga:37

Review paper

\title{
THE ROLE OF YOGA IN EDUGATION
}

\section{Daniela Cvitković}

Faculty of Education and Rehabilitation Sciences

University of Zagreb

Republic of Croatia

daniela.cvitkovic@erf.unizg.hr 


\section{ABSTRACT}

The aim of this paper is to explain the possibilities of applying yoga in education through the presentation of the conducted research. Yoga involves various techniques with the aim of achieving psychosocial balance. We are witnessing an increase in stress and emotional disorders in children; children are becoming more sedentary, and are preoccupied with the multitude of stimuli that come constantly via cell phone, computer, and television. By examining a series of research effects of yoga, we can conclude that yoga has proved to be effective in treating a variety of conditions and diseases. Practicing yoga can help reduce stress, anxiety symptoms, and depression. It examines the possibilities of introducing yoga as part of the school curriculum for healthy children and children with disabilities. Results have so far shown possible contributions of yoga in schools in the form of attention improvement, self-regulation and reduction of tension.

Keywords: yoga, education, schools, health. 


\section{INTRODUCTION}

Education is increasingly becoming a challenge in the world we live in. Surrounded by mobile phones and other forms of modern technology that bring something new every day, accustomed to speed, frequent activity changes and bombarded with stimuli, children come to schools where the most common method is listening and transcribing from the blackboard while sitting at a desk for six hours.

Excessive demands and too high expectations that are often put on children result in increasing stress and anxiety. Difficulties in meeting teachers and parents' expectations are often a cause of stress in children. At the same time, those same parents and teachers are often under stress themselves. We teach children, for example, about the reproduction of annelids, while no one teaches them how to breathe properly and thus reduce stress.

Young people are increasingly under stress. For example, in a Finnish study by Santalahti et al (2005), as many as 50\% of adolescents have symptoms of emotional and psychosomatic disorders. In a Croatian study, Vulić Prtorić and Lončarević (2016) found that $13-17 \%$ of students aged 11 to 15 experience intense internalized symptoms (stress, anxiety, depression). Stress levels are even higher in younger people compared to older people (Hagen, Nayar, 2014).

Chronic stress can result in many health problems such as anxiety, insomnia, muscle pain, high blood pressure and weakened immunity, heart disease, depression and others. (Hagen, Nayar, 2014). Attention levels are also strongly influenced by stress levels (Stueck and Gloeckner, 2005). Stress reduces the amount of norepinephrine, in charge of attention and mental vitality, and dopamine, which causes weakening of the enjoyment of activities that were previously enjoyable. It also reduces the amount of serotonin, which is responsible for good mood (Hagen, Nayar, 2014). On the other hand, it increases the level of cortisol, which is associated with the death of dendritic cells, atrophy of hippocampus, and thus with memory difficulties (Lupien et al., 1998).

In our Croatian education system, movement is limited to a physical education class. In addition, children are allowed to move during breaks, while during classes movement is prohibited or very restricted. Paradoxically, modern research suggests a direct link between movement and learning. Muscle activity, particularly coordinated, balanced movements, stimulate the production of neurotrophins, such as dopamine, which stimulate the growth of existing neurons and increase the number of new neurons and neural connections in the brain (Fotuhi, 2013; Hanaford, 1995). 
There is an urgent need for an education reform that would create a more conducive climate for learning in school and result in better outcomes. The aim of this paper is to describe the effects of practicing yoga on health through a review of research, and to analyze the applying possibilities and role of yoga in education for healthy students, but also for students with disabilities.

\section{WHAT IS YOGA?}

The word "yoga" comes from Sanskrit and has the original meaning of "unite, connect" (Paramhans Swami Maheshwarananda, 2006). In its original meaning, the word "yoga" means "an all-pervasive, eternally awake consciousness that keeps the entire universe in balance" (Paramhans Swami Maheshwarananda, 2006, 11).

Yoga refers to the goal, unity and harmony with oneself and others, but also to the methods by which that goal is achieved. The first written sources date, according to some sources, to around $3000 \mathrm{BC}$, but according to the scriptures, it can be assumed that the knowledge of yoga originates from much earlier, from the time when it was transmitted by the word of mouth (Kumar, 2008).

One of the fundamental works of the philosophy of yoga is "Yoga Sutra of Patanjali". Patanjali shaped the eight degrees of yoga: yama, niyama, asana, pranayama, pratyahara, dharana, dhyana, samadhi (Paramhans Swami Maheshwarananda, 2012). Yama and niyama relate to learning self-control and discipline, pranayama is a breathing exercise, pratyahara is a sensory withdrawal exercise, dharana are concentration exercises, dhyana is meditation, and samadhi is a state of unity consciousness. In accordance with Patanjali's "Yoga Sutras", it is still practiced all over the world today.

In a broader sense, yoga is a lifestyle that involves practicing awareness and achieving harmony using a variety of methods.

A typical yoga class begins with relaxation exercises. We consciously relax each part of the body for five to ten minutes. During relaxation, we focus on breathing and practice proper breathing, which, in addition to chest and clavicular breathing, also includes diaphragm breathing (so-called abdominal breathing). This is followed by dynamic exercises to warm up the joints, warm up and relax the muscles. Next are asanas. Asana means "position" (Paramhans Swami Maheshwarananda, 2012). Asanas are such positions that are the least tiring, and are beneficial for the psycho-physical state. Movement is aligned with breathing, while being aware of the motion. This is followed by a conscious breathing exercise (pranayama) and meditation. 
Relaxation at the beginning of exercises is very important because it brings a number of benefits. Conscious relaxation activates the circles of the parasympathetic system and thus strengthens them (Hanson, Mendius, 2014). It also calms the sympathetic nervous system (Hanson, Mendius, 2014). The relaxation response can even alter gene reflection and thus alleviate cell damage due to chronic stress (Hanson, Mendius, 2014). Relaxation can be achieved through conscious techniques of relaxation, breathing and meditation.

Breathing in yoga is conscious, which means controlled; it is deeper than during usual exercising. If, for example, we inhale and exhale five times, each time a little deeper than usually, it raises the energy level and relaxes; it first activates the sympathetic and then the parasympathetic nervous system, and can lead to the socalled flow or a meditative state known to athletes, artists, etc. (Hanson, Mendius, 2014).

Practicing yoga involves coordination of movements, stretching muscles in combination with abdominal breathing, which improves circulation and results in release of tension, increased oxygen, and has a beneficial effect on the central and autonomic nervous system (Peck et al., 2005).

When practicing yoga, the movements are performed consciously. Awareness activates central areas of the brain and improves coordination between the prefrontal cortex and the limbic system (Siegel, Barros, 2007).

Peck et al. (2005) emphasize the importance of body awareness. Body awareness allows us to also be aware of the feelings that manifest as physical reactions that the body creates. Yoga develops body awareness, which is confirmed by research (Peck et al., 2005). Body awareness can also lead to increased calmness, decreased tension, and improved concentration (Peck et al., 2005). Yoga exercises deactivate the sympathetic and stimulate the parasympathetic nervous system, which results in a sense of peace, emotional balance, improved concentration, and a sense of serenity (Peck et al., 2005).

Meditation is a part of yoga. According to Patanjali, dharana, a concentration exercise, precedes dhyana, a meditative state. Meditation can be described as the intentional regulation of attention to the present moment. It encompasses concentration, relaxation, altered states of consciousness, interruption of thought, and achieving the attitude of the self-observer (Paramhans Swami Maheshwarananda, 2012). It is described as a practice that puts the emphasis on achieving alertness, expanding self-awareness, and increasing cohesiveness (Peck et al., 2005). When experienced Tibetan meditation practitioners enter deep meditation, they emit gamma brain waves due to which large areas in the brain pulse in unison 30 to 80 times per second (Lutz, Brefczynski-Lewis, Johnstone and 
Davidson, 2004). Meditation increases the amount of gray matter in the insula (Hölzel et al., 2011; Lazar et al., 2005), hippocampus (Hölzel et al., 2011), and prefrontal cortex (Lazar et al., 2005; Luders et al., 2009). Furthermore, it has been found that meditation enhances the activation of left frontal areas, thus improving one's mood (Davidson, 2003).

Meditation also strengthens the immune system (Davidson, 2003; Tang et al., 2007). Meditation has been shown to help control the hypothalamic-pituitaryadrenal axis and related systems (e.g. the parasympathetic nervous system) which has the effect of reducing stress, improving digestion, immunity, and mood (Grossman et al., 2004; Carlson, Speca, Patel, 2003). During meditation, dopamine is released in the ventral striatum which is associated with behavioural control (Kjaer et al., 2002).

EEG studies have shown that the Sahaja Yoga Meditation system leads to an increase in alpha and theta waves in the frontal areas of the brain, and reduces the complexity of EEG patterns (Aftanas, Golocheikine, 2001, 2002). Reduced complexity of EEG patterns in the frontal areas of the brain is associated with the increased conscious control of cognitive processes (Aftanas, Golocheikine, 2001, 2002).

\section{YOGA PRACTICE ADJUSTMENTS FOR CHILDREN}

Yoga exercises, the way of performing and duration should be adapted to the psycho-physical abilities of children (Paramhans Swami Maheshwarananda, Maheshwarananda, Puchnarová, 1998). Exercises last less time, and the time can be gradually extended. Since the skeletal and hormonal systems are still developing, children should not stay in certain positions for too long. Practicing yoga also requires certain prerequisites, such as knowing the main parts of the body, knowing the breathing process, and distinguishing the state of tension from the state of relaxation. Graduality in the introduction of new exercises is also important; certain exercises can be performed only when the previous steps have been mastered. So, for example, pranayama exercises in children are performed only when they had mastered the process of proper breathing and can, to some extent, control that process. 


\section{THE IMPACT OF YOGA ON PSYCHO-PHYSICAL HEALTH}

A review of available research indicates that practicing yoga can improve the general physical condition, posture, strengthen immunity, and reduce and eliminate certain symptoms. Yoga can be an anti-stress technique and help reduce anxiety and depression, as well as affect psychological well-being which will now be briefly documented by available research.

Asanas help to adjust the vertebrae, increase flexibility, strengthen muscles and tendons, and thus contribute to proper posture (Khalsa, 2007). By practicing asanas and pranayama, internal organs are being regenerated, the epidermal, digestive, and cardiovascular systems are being cleansed of toxins and wastes, the nervous and endocrine systems are being balanced, and brain cells nourished (Khalsa, 2007). Exercise stabilizes blood pressure and heart rate in adults, children and adolescents (Bhargava et al., 1988; Birdee et al., 2009). The capacity of lungs is higher, breathing becomes more regular, and there is a fewer number of inhales and exhales per minute (Joshi, Joshi, Gokhale, 1992; Raub, 2002).

The potential effect of yoga on reducing stress, anxiety and depression, which are increasingly present in adults, but also in children, has been studied in several papers. Some research included self-assessments as a measure of emotional states, and some included physiological indicators.

Yoga has shown to be an effective anti-stress technique in both adults and children (Granath et al., 2006; Kalayil, 1988). Positive effects on anxiety and panic states have also been recorded (Telles, Gaur, Balkrishna, 2009; Kozasa et al., 2008; Kuttner et al., 2006; So, Orme-Johnson, 2001). Practicing yoga, unlike walking, increases the level of the GABA neurotransmitter, which plays a role in anxiety disorder (Karri, Yakhkind, Jensen, 2010). Yoga exercises have helped elementary school children reduce situational anxiety (Kalayil, 1988), whereas high school students became better at controlling anger, were less tired, reduced their anxiety, and improved their mood compared to the control group (Khalsa et al., 2012). The conclusion of a meta-analysis of 124 studies that dealt with the effects of yoga, practicing asanas, meditation and breathing, is that yoga can reduce depression (Balasubramaniam, Telles, Doraiswamy, 2013).

By practicing the "Siddha Samadhi Yoga" programme which includes meditations and pranayama, there were higher scores on the psychological wellbeing scale in adults (Kozasa et al., 2008). In a study involving 200 students aged 17 , a group practicing yoga reported higher levels of happiness and mental balance (Gupta, Singh, Singh, 2016). Meditation has been shown to increase empathy (Lazar et al., 2005; Lutz et al., 2008). 


\section{YOGA AND COGNITIVE FUNCTIONS}

Many studies confirm the effects of yoga practice on cognitive functions in both adults and children. Improvements in attention, perception, and memory have been confirmed, and some research indicate the possibility of influencing the speed of problem-solving and executive functions.

One of the first studies on the effects of yoga on attention in children was in the 1970s (Hopkins, Hopkins, 1979). The study involved 34 children aged six to 11. The children were divided into groups; one group exercised for 15 minutes, the other group had psychomotor exercises during that time. Concentration was measured through the score of one concentration game. Both groups significantly improved concentration. The disadvantage of the research is that there was no control group that did not do anything during that time.

Several studies that included a control group confirmed the effect of yoga on improving attention in both adults and children (Hopkins, Hopkins, 1979; Razza, Bergen-Cico, Raymond, 2015; Pradhan, Nagendra, 2010; Manjunath, Teles, 2001; Tang et al., 2007; Telles et al., 1993; Valentine, Sweet, 1999). Attention was measured by performance on tests, questionnaire assessments, and observation.

Nilsoge et al. (2016) found beneficial effects on working memory on a sample of 40 children without disabilities aged eight to 14 who practiced yoga, compared to the control group of children.

In another study, after one month of daily yoga programme lasting 75 minutes, the completion time of the mental health test in girls aged 10 to 13 decreased (Manjunath, Telles, 2001). In their review paper, Murphy, Donovan and Tailor (1997) point out that meditation, in addition to attention, also has a beneficial effect on perception and creativity, and reduces reaction time and field dependence. Similar conclusions were reached by So and Orme-Johnson (2001) studying the effects of TM meditation. As many as 154 students from a Chinese high school were divided into a meditation group and a control group. After six months of daily exercise for 20 minutes, there were significant shifts in the results of practical intelligence, field dependence, creativity, and information processing speed, compared to the control group.

Given that practicing yoga has an impact on cognitive abilities, it is reasonable to assume that it also improves school success, i.e. grades, which has been confirmed in several studies (Harrison, Manocha, Rubia, 2004; Kauts, Sharma, 2009). 


\section{YOGA AND SELF-REGULATION}

The effects of yoga on executive functions, such as planning, learning regulation, and self-monitoring, which play a very important role in the learning process, were also studied. In a study by Manjunatha and Telles (2004), there was an improvement in planning, task-solving speed, and memory in a group of children who practiced yoga, while there was no improvement in a group of children who engaged in other physical activity. Self-regulation is one of the most important components of school readiness (Blair 2002; Raver 2004), as it affects peer acceptance and school success (Blair, Razza 2007; Ladd Birch, Buhs, 1999; McClelland, Morrison, Holmes, 1999). It is also associated with self-esteem, health, and achievement (Moffitt et al., 2011; Shoda, Mischel, Peake, 2000).

Razza et al. (2015) examined the effectiveness of a yoga-based intervention on improving self-regulation in preschool children (aged three to five). Significantly greater progress was made on all measures of self-regulation, delay of gratification, and inhibition control in the experimental group, compared to the control group.

Ramadoss and Bose (2010) found significant improvements in self-control in a group of 190 high school students who practiced yoga, compared to the control group. Similar results were obtained by Khalsa et al. (2012) and Noggle et al. (2012); groups of high school students who practiced yoga were significantly better at controlling anger.

\section{YOGA FOR CHILDREN WITH DISABILITIES}

Practice and research have shown that children with disabilities are able to practice yoga and benefit from the exercise.

A recent study examined the possibilities and impact of practicing yoga in 29 children with autism spectrum disorder (Sotoodeh et al., 2017). A yoga instructor had practiced with each child individually for 30 minutes, three times a week for eight weeks. There have been significant shifts in The Autism Treatment Evaluation Checklist (ATEC) in all areas except spoken language communication.

Uma et al. (1989) investigated the effect of yoga in children with intellectual disabilities. Ninety children were divided into an experimental group that practiced yoga, and a control group that participated in normal school activities for one hour each day for one school year. The group that practiced yoga made significant progress on intelligence tests, psychomotor and social skills, as opposed to the control group. 
It was further found that meditation can reduce anxiety, improve social skills, and academic achievement in adolescents with specific learning difficulties (Beauchemin, Hutchins, Patterson, 2008).

Possibilities of introducing yoga as part of the school curriculum for children with mood and behavioural disorders were also explored. After three and a half months of exercising one hour, twice a week during class, teachers reported better attention and reduction in symptoms of mood and/or behavioral disorders (Steiner et al., 2013).

Yoga is increasingly practiced by children with cerebral palsy. In one case study, there was a shift in posture, balance control, flexibility, and functional mobility in a nine-year-old girl who practiced yoga following a six-week programme tailored for people with motor impairments (Bugajski et al., 2013).

A number of studies have confirmed that practicing yoga reduces the symptoms of attention deficit and hyperactivity disorder (ADHD), i.e. it improves attention while reducing hyperactivity and impulsivity. There have also been significant shifts in parent and teacher assessments (Boeshansz, 2009; Grosswald et al., 2008; Chou, Huang, 2017; Hariprasad et al., 2013; Harrison, Manocha, Rubia, 2004; Jensen, Kenny, 2004; Shannahoff-Khalsa, 2004) and in attention and reaction time tests (Chou, Huang, 2016). Some research has found that - in addition to attention - organizational skills, reading, and writing in children with ADHD can be improved (Mehta Shah et al., 2012), and oppositional behaviour can be reduced (Redfering, Bowman, 1981).

By practicing yoga together, parents and children have opportunities to improve their relationship as well. This was demonstrated by Harrison, Manocha and Rubia (2004) investigating the effect of Sahaja meditation on families with 48 children with ADHD. There have been significant shifts in self-esteem, school success, parent-child relationship, and reduction in ADHD symptoms in children. Anxiety has also decreased. Some children have discontinued medical therapy or reduced the dose of medication. These children had even greater effects by meditating. Many children stated that they fall asleep and concentrate more easily. They reported fewer problems with peers. Ninety-two percent (92\%) of parents reported significant changes and their satisfaction with the programme. There was no progress in the control group while they waited for the programme; there were also significant changes after the programme.

Hariprasad et al. (2013) showed that yoga can also be practiced by children with very pronounced symptoms of ADHD. Nine children aged five to 16 with very pronounced $\mathrm{ADHD}$ symptoms exercised each day with their parents during their hospital stay. They continued to exercise at home three times a week for 
one month. They all progressed in performing the exercises and the symptoms decreased. A couple of months later, when they stopped exercising, the symptoms worsened.

\section{YOGA IN SGHOOLS}

Based on the review of research on the effects of yoga so far, it can be assumed that yoga could be very much welcome as part of the school curriculum helping to achieve the planned outcomes.

Yoga is already a part of the curriculum in nine thousand US schools. More than 5,400 yoga instructors have been trained for conducting yoga programmes in schools (Khalsa, Butzer, 2016).

The number of yoga programme evaluation studies as part of the school curriculum is growing exponentially. Six studies were published in the period from 2005 to 2009, the number increased to 30 in the period from 2010 to 2014, while in 2015 there were 11 studies published (Khalsa, Butzer, 2016). Most studies have been conducted in the US and India. One available study is from Israel and one from Germany. Although yoga has been practiced in European schools for more than 30 years, according to the programmes of various schools, there are no European research in the available databases. The "Research on Yoga in Education" programme founded by Flak (http://www.ryeuk.org/) is present in some European countries (France, UK, Italy, Belgium, etc.). According to the "Yoga in daily life" system by Paramhans Swami Mahewswarananda, it is also practiced in many countries in Europe, America, Australia, Asia, and even Africa. Many teachers in Croatia have completed their education according to the "Yoga in daily life" system and use their knowledge in working with students.

Yoga as a programme was most often offered at a time when other students were having physical education classes, but on multiple occasions some teachers incorporated exercises during or after classes. Most yoga programmes are conducted by trained yoga instructors, and in some programmes, teachers are trained by yoga instructors.

Based on the available data, three systematic review papers related to the area of yoga-based school interventions have been conducted so far. The last systematic analysis was in 2016 (Khalsa, Butzer, 2016).

Subsequently, a number of other papers in this field were published, only some of which met strict methodological criteria, meaning that they included experimental and control groups in which participants were selected randomly (so-called randomized controlled trials). 
A systematic analysis of 12 studies (Serwacki, Cook-Cottone, 2012) indicates multiple benefits of practicing yoga during classes for healthy children, but also for children with autism, intellectual disabilities, learning difficulties, and emotional difficulties. Attention, concentration, and self-esteem have increased in students, stress coping strategies have improved, and stress, anxiety, and emotional arousal have decreased (Serwacki, Cook-Cottone, 2012). The authors state that although yoga-based interventions show some positive outcomes, methodological limitations of some research (quasi-experimental plans, cohort studies, insufficiently described intervention programmes) prevent definitive conclusions from being drawn.

The following systematic analysis of nine studies that met methodological criteria (Ferreira-Vorkapic et al., 2015) found small- to medium-size effects for measures of mood, tension, anxiety, self-esteem, and memory.

Two studies state that there was a higher level of stress during and after practicing yoga (Haden, Daly, Hagins, 2014; White, 2012), compared with the control group and the group that had a normal physical education class. They give possible explanations for these negative effects. They state that yoga exercises are new to children and require adjustment and effort in the initial period which can be stressful. Therefore, they recommend that the impact of yoga on stress is examined after the initial period, that is, after the intervention. As another possible reason for the increased stress, they cite the inadequacy of certain techniques, such as breathing exercises for children, and emphasize the need to adjust the yoga programme with regard to children's age. Breathing exercises can also be practiced by children, but it is necessary to achieve the prerequisites previously described in this paper. The authors of research in which there was greater stress in individual children (Haden, Daly, Hagins, 2014; White, 2012) as a possible explanation suggest that students with awareness training through yoga became more aware of emotions, which may initially result in greater stress, but ultimately in finding better ways to deal with emotions.

Ferreira-Vorkapic et al. (2015) further argue that the positive effects of practicing yoga were shown in shorter programmes lasting 15 to 30 minutes, and that programmes of longer duration are too demanding for children. However, there are studies that speak in favor of the positive effects of practicing yoga in 45-minute programmes as well (Telles et al., 2013; Verma et al., 2014).

The fact is that in most papers, yoga programmes are not described in detail, and we cannot determine how suitable certain programmes are for children. Only the names of the programmes are given, for example, "Kripalu Yoga" (Noggle, 2012), "The Mindful Awareness for Girls through Yoga" (White, 2012), "Yoga 
Fitness for Kids" (Peck et al., 2005), Marsha Wenig's yoga programme (Boeshnaz, 2009), and techniques covered by the programmes, for the most part asanas, exercises for relaxation, breathing, meditation, or guided imagination.

A year later, a critical analysis of yoga research in schools was conducted by Kalsa and Butzer (2016). Of 47 studies included in the analysis, 27 met the most stringent methodological criteria. The authors conclude that, despite the difficulties of comparing research arising from heterogeneity in yoga programmes and the different duration of programmes, the research findings suggest positive effects of yoga practice. The authors also emphasize the need for more methodologically adequate research that would include various measures of effect, such as psychophysiological measures.

Following these systematic analyses, a few more quantitative randomized experimental studies evaluating the effects of yoga programmes have been published. The "Transformative Life Skills" programmethat includes teaching about stress, reaction to stress, exercising asanas, relaxation, breathing, and meditation (Frank et al., 2017) showed a significant increase in emotional regulation, positive thoughts, and cognitive restructuring in response to stress, compared to the control group. There was no significant effect on somatization measures, school success, and general mood. The students accepted the programme well and found it useful. In addition to experimental plans involving quantitative methods, some of the researchers tried to use qualitative methods to examine the effectiveness of yoga as part of the school curriculum. Yoga practitioners often notice non-specific changes that are difficult to measure by classical quantitative methods. Qualitative methods, which collect data on life experiences, are a good tool precisely for researching such complex, unique experiences (Conboy et al., 2013). By reviewing research that included qualitative methods, we can conclude that most participants report positive experiences during and after practicing yoga. Elementary and high school students also reported that practicing yoga helped them recognize signs of stress, and that they used some exercises in stressful and emotionally demanding situations (Conboy, 2013; Mendelson et al., 2010; Charbonneau, 2011; Thomas, 2014), when angry (Thomas, 2014), before going to bed, and in other situations (Butzer et al., 2017; Thomas, 2014; Conboy, 2013). Older students, aged 15 to 16, noticed increased awareness of the body, thoughts and emotions (Charbonneau, 2011). They stated that they felt calmer after relaxation and breathing exercises (Conboy, 2013; Thomas, 2014).

Some studies have reported that a small number of students did not like yoga programmes, mostly because they were held at the same time as other students had their usual physical education class (Butzer et al., 2017; Conboy et al., 2013). 
Three studies included teachers' observations and interviews (Thomas, 2014; Tubbs, 2018; Mendelson et al., 2010). The teachers observed positive changes in concentration, learning, and behavior (Thomas, 2014; Tubbs, 2018; Mendelson et al., 2010).

Two studies have explored the possibility of implementing yoga in schools as a form of intervention for children with attention deficit disorder. Peck et al. (2005) conducted a study that included a control group, and attention was measured as time spent on the task, whereas in a study conducted by Boeshanzs (2009), teachers' attention assessments were compared before and after the intervention, and there was no control group. Although the results indicate a favorable effect on attention in both studies, due to small samples and methodological shortcomings, no serious conclusions can be drawn about the effectiveness of programmes designed specifically for groups of children with these difficulties. In both studies, children with attention deficit disorder were able to practice according to instructions for up to 30 minutes, which indicates children's ability to practice yoga in a school context despite the difficulties.

Yoga programmes are also being introduced at the preschool level. Several studies have addressed the possibilities and effects of applying yoga in kindergartens. Only one of them involved a randomized plan with a control group. Razza et al. (2015) examined the effectiveness of a yoga-based intervention on improving self-regulation in preschool children aged three to five. There were 16 children in the experimental group and 13 in the control group. The educator led the "Yoga Kids" programme (Wenig, 2003) for a year. The programme lasted from the initial 10 minutes to 30 minutes a day, and consisted of breathing exercises and sun salutations in the morning, asanas were following literary activities in the afternoon, and breathing exercises were put in between. Significant advances were made in all self-regulatory measures - attention, delay in meeting needs, and inhibition control in the experimental group with significant differences in self-regulation at the end of the programme, compared to the control group. Most progress happened in those children who were most at risk for self-regulation dysfunction.

Meditations are increasingly pervasive as youth programmes in schools, community, and clinical practice. Thousands of students in the US have undergone a Transcendental Meditation (TM) programme through "The David Lynch Foundation". The programme is intended for students from the age of 10 onward as a treatment for ADHD, emotional problems, and learning difficulties. "The US Committee for Stress-Free Schools" founded in 2005 provided TM programmes to students and teachers across the US a (Black, Milam, Sussman, 2008). Students 
have a meditation programme twice a day for 15 minutes. Evaluation of the effects of TM in relation to the control group showed progress in intelligence (So, OrmeJohnson, 2001), learning, academic success (Nidich et al., 2011), psychological well-being (Wendt, Hipps, Abrams, 2015), reducing anxiety (Elder et al., 2011) and drug use (Monahan, 2009). The programme also resulted in a lower dropout rate (Colbert, 2013). It turned out to be good for children with ADHD; the impact was manifested on attention, organizational skills, learning independence, better sleep, better EEG image, and the effects remained present even after three months (Travis, Grosswald, Stixrud, 2011).

In addition to the studies described here, a number of studies with greater methodological limitations have been conducted, such as a plan that does not include a control group, includes only small samples, has insufficiently described interventions, etc. Research into the effects of yoga in school are quite heterogeneous in terms of the type, duration and manner of implementation of yoga programmes, sample size, student age, and assessment methods, and are therefore difficult to compare.

Although most programmes include exercises that traditionally belong to yoga, they differ in the choice and order of exercises, as well as the way they are performed and the approach of the instructor. Due to that, the outcomes of individual programmes may differ. Many programmes, not having knowledge of how to perform and effects, have taken some yoga exercises from the traditional corpus while excluding some exercises without which the effect is not complete. Many programmes that were a part of individual research lasted very short. Given the duration of the programme, it is logical to expect that programmes that last longer will produce greater changes in the practitioners. It is unrealistic to expect a short-term programme to lead to complex and process changes on the cognitive and socioemotional level. Research also differ in the selected measuring instruments. Certain subtle changes can only be captured by appropriately selected assessment methods, and the conclusion that there are no changes after the programme may be incorrect. Some research has failed to determine the effectiveness of yoga, while most have confirmed the specific contribution of yoga to stress, self-regulation, and cognitive abilities found in evaluations of yoga programmes in centers outside of school.

From the research above, it can be concluded that replacing physical education or some other leisure activity with yoga is not a good way of introducing yoga into the school curriculum. It seems that practicing yoga as a separate activity in school and practicing some yoga techniques several times a day, for example at the beginning of a class, can yield good results. 


\section{CONCLUSION}

By reviewing a series of research, this paper sought to contribute to answering the question of the role of yoga in education. Interest in researching the possibilities of yoga as a therapy for various conditions and diseases, as a form of prevention and intervention in children with disabilities, and as part of the school curriculum is growing. Previous research confirms the effects of yoga on health condition, cognitive functions, emotions, and self-regulation. In schools that introduced yoga as part of the curriculum, there has been a reduction in stress, improved mood, increased attention and calm in some children, which are prerequisites for successful learning. Possible benefits have been demonstrated through the use of yoga exercises during breaks, during classes, and as a separate activity.

Following the above, we can conclude that yoga could play a significant role in education by helping to achieve outcomes and encourage psychosocial development. 


\section{REFERENCES}

1. Aftanas, L. I., Golocheikine, S. A. (2001). Human anterior and frontal midline theta and lower alpha reflect emotionally positive state and internalized attention: high-resolution EEG investigation of meditation. Neuroscience letters, 310 (1), 57-60.

2. Aftanas, L. I., Golocheikine, S. A. (2002). Non-linear dynamic complexity of the human EEG during meditation. Neuroscience letters, 330 (2), 143-146.

3. Balasubramaniam, M., Telles, Doraiswamy, P. M. (2013). Yoga on our minds: a systematic review of yoga for neuropsychiatric disorders. Frontiers in Psychiatry, 3, 117. https://doi.org/10.3389/ fpsyt.2012.00117

4. Beauchemin, J., Hutchins, T. L., Patterson, F. (2008). Mindfulness Meditation May Lessen Anxiety, Promote Social Skills, and Improve Academic Performance Among Adolescents With Learning Disabilities, Journal of Evidence-Based Complementary \& Alternative Medicine, 13 (1), 34-45.

5. Bhargava, R., Gogate, M. G., Mascarenhas, J. F. (1988). Autonomic responses to breath holding and its variations following pranayama. Indian Journal of Physiology and Pharmacology, 32 (4), 257-263.

6. Birdee, G. S., Yeh, G. Y., Wayne, P. M., Phillips, R. S., Davis, R. B., Gardiner, P. (2009). Clinical applications of yoga for the pediatric population: A systematic review. Academic Pediatrics, 9, 212-220.

7. Black, D. S., Milam, J., Sussman, S. (2008). Sitting-meditation interventions among youth: A review of treatment efficacy. Pediatrics, 124, 532-541.

8. Blair, C. (2002). School readiness as propensity for engagement: Integrating cognition and emotion in a neurobiological concep-tualization of child functioning at school entry. American Psychologist, 57 (2), 111-127.

9. Blair, C., Razza, R. P. (2007). Relating effortful control, executive function, and false belief understanding to emerging math and literacy ability in kindergarten. Child Development, 78 (2), 647-663.

10. Boeshanzs, M. (2009). The Effects of Curriculum Based Yoga on Children With Attention Deficit/ Hyeractivity Disorder. Available from ProQuest Dissertations \& Theses Global.

11. Bugajski, S., Christian, A., O'Shea, R. K., Vendrely, A. M. (2013). Exploring Yoga’s Effects on Impairments and Functional Limitations for a Nine-Year-Old Female with Cerebral Palsy: A Case Report. Journal of Yoga and Physical Therapy, 3, 140-146.

12. Butzer, B., LoRusso, A. M., Windsor, R., Riley, F., Frame, K., Khalsa, S., Conboy, L. (2017). A Qualitative Examination of Yoga for Middle School Adolescents. Advances in school mental health promotion, 10 (3), 195-219.

13. Butzer, B., LoRusso, A., Shin, S. H., Khalsa, S. B. S. (2017). Evaluation of yoga for preventing adolescent substance use risk factors in a middle school setting: a preliminary group-randomized controlled trial. Journal of youth and adolescence, 46 (3), 603-632.

14. Carlson, L. E., Speca, M., Patel, K. D. (2003). Mindfulness-based stress reduction in relation to quality of life, mood, symptoms of stress, and immune parameters in breast and prostate cancer outpatients. Psychosomatic Medicine, 65 (4), 571-581. 
15. Charbonneau, C. M. (2011). Learning in Small Moments - The Effects of The Practice of Kundalini Yoga on Middle Years Students in an Urban School. Available from ProQuest Dissertations \& Theses Global.

16. Chou, C.-C., Huang, C.-J. (2017). Effects of an 8-week yoga program on sustained attention and discrimination function in children with attention deficit hyperactivity disorder. Peer Journal, 5 , e2883.

17. Colbert, R. (2013). Effect of the Transcendental Meditation Program on Graduation, College Acceptance and Dropout Rates for Students Attending an Urban Public High School. Education, 4 (7), 495-501.

18. Conboy, L. A., Noggle, J. J., Frey, J. L., Kudesia, R. S., Khalsa, S. B. S. (2013). Qualitative evaluation of a high school yoga program: feasibility and perceived benefits. Explore: The Journal of Science and Healing, 9, 171-180.

19. Davidson, R. J., Kabat-Zinn, J., Schumacher, J., Rosenkranz, M., Muller, D., Santorelli, S. F., ... \& Sheridan, J. F. (2003). Alterations in brain and immune function produced by mindfulness meditation. Psychosomatic medicine, 65 (4), 564-570.

20. Elder, C., Nidich, S., Colbert, R., Hagelin, J., Grayshield, L., Oviedo-Lim, D. (2011). Reduced psychological distress in racial and ethnic minority students practicing the Transcendental Meditation program. Journal of Instructional Psychology, 38 (2), 109-117.

21. Ferreira-Vorkapic, C., Feitoza, J. M., Marchioro, M., Simões, J., Kozasa, E., Telles, S. (2015). Are there benefits from teaching yoga at schools? A systematic review of randomized control trials of yoga-based interventions. Evidence-Based Complementary and Alternative Medicine, 2015. https://doi.org/10.1155/2015/345835

22. Fotuhi, M. (2013). Boost your brain: The new art and science behind enhanced brain performance. New York: HarperOne.

23. Frank, J. L., Kohler, K., Peal, A., Bose, B. (2017). Effectiveness of a school-based yoga program on adolescent mental health and school performance: Findings from a randomized controlled trial. Mindfulness, 8 (3), 544-553.

24. Granath, J., Ingvarsson, S., Von Thiele, U., Lundberg, U. (2006). Stress management: a randomized study of cognitive behavioural therapy and yoga. Cognitive Behaviour Therapy, 35 (1), 3-10.

25. Grossman, P., Niemann, L., Schmidt, S., Walach, H. (2004). Mindfulness-based stress reduction and health benefits: A meta-analysis. Journal of psychosomatic research, 57 (1), 35-43.

26. Grosswald, S. J., Stixrud, W. R., Travis, F., Bateh, M. A. (2008). Use of the Transcendental Meditation technique to reduce symptoms of Attention Deficit Hyperactivity Disorder (ADHD) by reducing stress and anxiety: An exploratory study. Current Issues in Education 10 (2), 1-10.

27. Gupta, R. K., Singh, S., Singh, N. (2016). Does yoga influence happiness and mental balance: a comparison between yoga practitioners and non yoga practitioners?. Online Journal of Multidisciplinary Research (OJMR), 2 (3), 1-5.

28. Haden, S. C., Daly, L., Hagins, M. (2014). A randomised controlled trial comparing the impact of yoga and physical education on the emotional and behavioural functioning of middle school children. Focus on Alternative and Complementary Therapies, 19 (3), 148-155.

29. Hagen, I., Nayar U. S. (2014). Yoga for children and young people's mental health and well-being: Research review and reflections on the mental health potentials of yoga. Frontiers in Psychiatry, 5, $1-6$. 
30. Hagins, M., Haden, S. C., Daly, L. A. (2013). A Randomized Controlled Trial on the Effects of Yoga on Stress Reactivity in 6th Grade Students," Evidence-Based Complementary and Alternative Medicine, 2013, 1-9.

31. Hanson, R., Mendius, R. (2014). Budin mozak. Zagreb: V.B.Z. d.o.o.

32. Hariprasad, V. R., Arasappa, R., Varambally, S., Srinath, S., Gangadhar, B. N. (2013). Feasibility and efficacy of yoga as an add-on intervention in attention deficit-hyperactivity disorder: An exploratory study. Indian Journal of Psychiatry, 55 (3), 379-384.

33. Harrison, L. J., Manocha, R., Rubia, K. (2004). Sahaja yoga meditation as a family treatmentYoga Intervention 57 programme for children with attention deficit- hyperactivity disorder. Clinical Child Psychology and Psychiatry, 9(4), 479-497.

34. Hölzel, B. K., Carmody, J., Vangel, M., Congleton, C., Yerramsetti, S. M., Gard, T., Lazar, S. W. (2011). Mindfulness practice leads to increases in regional brain gray matter density. Psychiatry Research: Neuroimaging, 191 (1), 36-43.

35. Hopkins, J. T., Hopkins, L. J. (1979). A study of yoga and concentration. Academic Therapy, 14 (3), 341-345.

36. Jensen, P. S., Kenny, D. T. (2004). The effects of yoga on the attention and behavior of boys with attention-deficit/hyperactivity disorder (ADHD). Journal of attention disorders, 7 (4), 205-216.

37. Joshi, L. N., Joshi, V. D., Gokhale L. V. (1992). Effecf of short term 'pranayam' practice on breathingrate and ventilatory funcfions of lung. Indian Journal of Physiology and Pharmacology, $36(2), 105-108$.

38. Kalayil, J, A. (1988). A controlled comparison of progres-sive relaxation and yoga meditation as methods to relieve stress in middle grade school children. Dissertation Abstracts International, 49, 3626.

39. Karri, S. K., Yakhkind, A., Jensen, J. E. (2010). Effects of Yoga Versus Walking on Mood, Anxiety, and Brain GABA Levels: A Randomized Controlled MRS Study. Journal of Alternative and Complementary Medicine, 16 (11), 1145-1152.

40. Kauts, A., Sharma N. (2009). Effects of yoga on academic performance in relation to stress. International Journal of Yoga, 2 (1), 39-43.

41. Kenny, M. (2002). Integrated movement therapy: Yoga-based therapy as a viable and effective intervention for autism spectrum and related disorders. International Journal of Yoga Therapy, 12, 71-79.

42. Khalsa, S. B. (2007). Yoga as a therapeutic intervention. Principles and practice of stress management, 3, 449-462.

43. Khalsa, S., Hickey-Schultz, L., Cohen, D., Steiner, N., Cope S. (2012). Evaluation of the Mental Health Benefits of Yoga in a Secondary School: A Preliminary Randomized Controlled Trial. The Journal of Behavioral Health Services \& Research, 39 (1), 80-90.

44. Khalsa, S., Butzer, B. (2016). Yoga in school settings: a research review. Annals of the New York Academy of Sciences, 1373 (1), 45-55.

45. Kjaer, T. W., Bertelsen, C., Piccini, P., Brooks, D., Alving, J., Lou H. C. (2002). Increased dopamine tone during meditation-induced change of consciousness. Brain Res Cogn Brain Res. 13 (2), 255259. 
46. Kozasa, E. H., Santos, R. F., Rueda, A. D., Benedito-Silva, A. A., De Moraes Ornellas, L., Leite, J. R. (2008). Evaluation of Siddha Samadhi yoga for anxiety and depression symptoms: a preliminary study. Psychological Reports, 103 (1), 271-274.

47. Kumar, B. M. (2008). Forestry in ancient India: some literary evidences on productive and protective aspects. Asian Agri-History, 12 (4), 299-306.

48. Kuttner, L., Chambers, C. T., Hardial, J., Israel, D. M., Jacobson, K., Evans, K. (2006). A Randomized Trial of Yoga for Adolescents with Irritable Bowel Syndrome. Pain Research and Management, 11 (4), 217-224.

49. Ladd, G. W., Birch, S. H., Buhs, E. S. (1999). Children's social and scholastic lives in kindergarten: Related spheres of influence?. Child Development, 70 (6), 1373-1400.

50. Lazar, S. W., Kerr, C. E., Wasserman, R. H., Gray, J. R., Greve, D. N., Treadway, M. T., ... Rauch, S. L. (2005). Meditation experience is associated with increased cortical thickness. Neuroreport, 16 (17), 1893.

51. Luders, E., Toga, A. W., Lepore, N., Gaser, C. (2009). The underlying anatomical correlates of long-term meditation: larger hippocampal and frontal volumes of gray matter. Neuroimage, 45 (3), 672-678.

52. Lupien, S. J., De Leon M., De Santi S., Convit, A., Tarshish, C., Nair, N. P. V., Thakur, M., McEwen, B. S., Hauger, R. L., Meaney, M. J. (1998). Cortisol levels during human aging predict hippocampal atrophy and memory deficits. Nature Neuroscience, 1 (1), 69-73.

53. Lutz, A., Brefczynski-Lewis, J., Johnstone, T., Davidson, R. J. (2008). Regulation of the neural circuitry of emotion by compassion meditation: effects of meditative expertise. PloS one, 3 (3), e1897.

54. Maheshwarananda, S. P., Puchnarová, D. (1998). Yoga mit Kindern. Hugendubel.

55. Manjunath, N., Telles, S. (2001). Improved performance in the Tower of London test following yoga. Indian Journal of Physiology and Pharmacology, 45 (3), 351-354.

56. Manjunath, N., Telles, S. (2004). Spatial and verbal memory test scores following yoga and fine arts camps for school children. Indian Journal of Physiol Pharmacology, 48 (3), 353-356.

57. McClelland, M., Morrison, F. J., Holmes, D. L. (2000). Children at risk for early academic problems: The role of learning-related social skills. Early Childhood Research Quarterly, 15 (3), 307-329.

58. Mehta, S., Shah, D., Kushal, S., Mehta, S., Mehta, N., Mehta, V., Motiwala, S., Mehta, N., Mehta, D. (2012). Peer-Mediated Multimodal Intervention Program for the Treatment of Children with ADHD in India: One-YearFollowup. International Scholarly Research Network ISRN Pediatrics, $1-7$.

59. Mendelson, T., Greenberg, M. T., Dariotis, J. K., Gould, L. F., Rhoades, B. L., Leaf, P. J. (2010). Feasibility and preliminary outcomes of aschool-based mindfulness intervention for urban youth. Journal of Abnormal Child Psychology, 38, 985-994.

60. Moffitt, T. E., Arseneault, L., Belsiky, D., Dickson, N., Hancox, R. J., Harrington, H. (2011). A gradient of childhood self-control predicts health, wealth, and public safety. PNAS, 108, 26932698.

61. Monahan, R. (2009). Secondary Prevention of Drug Dependence through the Transcendental Meditation Program in Metropolitan Philadelphias. International Journal of the Addictions, 12 (6), 729-754. 
62. Murphy, M., Donovan, S., Taylor, E. (1997). The Physical and Psychological Effects of Meditation: A Review of Contemporary Research With a Comprehensive Bibliography, 1931-1996. Sausalito, CA: Institute of Noetic Sciences.

63. Nidich, S., Mjasiri, S., Nidich, R., Rainforth, M., Grant, J., Valosek, L. (2011). Academic achievement and transcendental meditation: a study with at-risk urban middle school students. Education, 131 (3), 556-564.

64. Nilsoge, D., Bagade, A., Tumbigeremutt, V., Kulkarni, P., Rao, S. B., Bhat, A., Darshan, M. (2016). Evaluation of Attention and Verbal Memory in Yoga Practicing Pre-Adolescents: A CrossSectional Study. Journal of Restorative Medicine, 5, 3-13.

65. Noggle, J. J., Steiner, N. J., Minami, T., Khalsa, S. B. (2012). Benefits of yoga for psychosocial well-being in a US high school curriculum: a preliminary randomized controlled trial. Journal of Developmental and Behavioral Pediatrics, 33, 193-201.

66. Paramhans Swami Maheshwarananda (2012). Patanđalijeve joga sutre, Samadhi pada. DNM d.o.o., Zagreb.

67. Paramhans Swami Maheshwarananda (2006). Skrivene snage u čovjeku, Zagreb: DNM d.o.o.

68. Peck, H. L., Kehle, T. J., Bray, M. A., Theodore, L. A. (2005). Yoga as an intervention for children with attention problems. School Psychology Review, 34 (3), 415-424.

69. Pradhan, B., Nagendra, H. R. (2010). Immediate effect of two yoga-based relaxation techniques on attention in children. International journal of yoga, 3(2), 67.

70. Ramadoss, R., Bose, B. (2010). Transformative life skills: pilot studies of a 6 yoga model for reducing perceived stress and improving self-control in vulnerable youth. International Journal of Yoga Therapy, 20, 75-80.

71. Raub, J. (2002). Psychophysiologic Effects of Hatha Yoga on Musculoskeletal and Cardiopulmonary Function: A Literature Review, The Journal Of Alternative And Complementary Medicine, 8, 797-812.

72. Raver, C. C. (2004). Placing emotional self-regulation in sociocultural and socioeconomic contexts. Child Development, 75, 346-353.

73. Razza, R. A., Bergen-Cico, D., Raymond, K. (2015). Enhancing Preschoolers' Self-Regulation Via Mindful Yoga. Journal of Child and Family Studies, 24 (2), 372-385.

74. Redfering, D. L., Bowman, M. J. (1981). Effect of a meditative yoga relaxation exercise on nonattending behaviors of bchaviorally disturbed children. Clinical Child Psychology, 10, 126-127.

75. Santalahti, P., Aromaa, M., Sourander, A., Helenius, H., Piha, J. (2005). Hove there been changes in children's psychosomatic symptoms? A 10-year comparasion from Finland, Pediatrics, 115 (4), 434-442.

76. Serwacki, M. L., Cook-Cottone, C. (2012). Yoga in the schools: a systematic review of the literature. International Journal of Yoga Therapy, 22, 101-109.

77. Shannahoff-Khalsa, D. (2004). An introduction to kundalini yoga meditation techniques that are specific for the treatment of psychiatric disorders. The Journal of Alternative and Complementary Medicine, 10 (1), 91-101.

78. Shoda, Y., Mischel, W., Peake, P. K. (1990). Predicting adolescent cognitive and self-regulatory competencies from preschool delay of gratification: Identifying diagnostic conditions.

Developmental Psychology, 26 (6), 978-986. 
79. Siegel, P., Barros, N. F. (2007). Yoga and Health: a systematic literature review. New Approaches to Medicine and Health (NAMAH), 14 (4), 40-50.

80. So, K., Orme-Johnson, D. W. (2001). Three randomized experiments on the longitudinal effects of the Transcendental Meditation technique on cognition. Intelligence, 29 (5), 419-440.

81. Sotoodeh, M. S., Arabameri, E., Panahibaksh, M., Ghanizadeh, A. (2017). Effectiveness of yoga training program on the severity of autism. Complementary Therapies in Clinical Practice, 1-7.

82. Steiner, N. J., Sidhu, T. K., Pop, P. G., Frenette, E. C., Perrin, E. C. (2013). Yoga in an Urban School for Children with Emotional and Behavioral Disorders: A Feasibility Study, Journal of Child Family Study, 22, 815-826.

83. Stueck, M., Gloeckner, N. (2005). Yoga for children in the mirror of the science: Working spectrum and practice fields of the training of relaxation with elements of yoga for children. Early child development and care, 175 (4), 371-377.

84. Tang, Y. Y., Ma, Y., Wang, J., Fan, Y., Feng, S., Lu, Q., ... \& Posner, M. I. (2007). Short-term meditation training improves attention and self-regulation. Proceedings of the National Academy of Sciences, 104 (43), 17152-17156.

85. Telles, S., Gaur, V., Balkrishna, A. (2009). Effect of a yoga practice session and a yoga theory session on state anxiety. Perceptual and Motor Skills, 109 (3), 924-930.

86. Telles, S., Hanumanthaiah, B., Nagarathna, R., Nagendra, H. R. (1993). Improvement in static motor performance following yogic training of school children. Perceptual and Motor Skills, 76 (3_suppl), 1264-1266.

87. Telles, S., Singh, N., Bhardwaj, A. K., Kumar, A., Balkrishna, A. (2013). Effect of yoga or physical exercise on physical, cognitive and emotional measures in children: a randomized controlled trial. Child and Adolescent Psychiatry and Mental Health, 7 (37), 1-16.

88. Thomas, E. M. (2014). Yoga and breathing and relaxation techniques used during the school day and their effects on school-aged children. Wayne State University.

89. Travis F., Grosswald, S., Stixrud, W. (2011). ADHD, Brain Functioning, and Transcendental Meditation. PracticeMind \& Brain, The Journal of Psychiatry, 2 (1), 73-81.

90. Tubbs, D. K. (2008). Integrating yoga as part of the curriculum in public schools (Doctoral dissertation). ProQuest Dissertations \& Theses Global.

91. Uma, K., Nagendra, H. R., Nagarathna, R., Vaidehi, S., Seethalakshmi, R. (1989). The integrated approach of yoga: A therapeutic tool for mentally retarded children: A oneyear study. Journal of Mental Deficiency Research, (33), 415-421.

92. Valentine, E. R., Sweet, P. L. (1999). Meditation and attention: A comparison of the effects of concentrative and mindfulness meditation on sustained attention. Mental Health, Religion \& Culture, 2 (1), 59-70.

93. Verma, A., Shete, S. U., Singh Thaku, G., Devarao Kulkarni, D., Singh Bhogal, R. (2014). The effect of yoga practices on cognitive development in rural residential school children in India. National Journal of Laboratory Medicine, 3 (3), 15-19.

94. Vulić-Prtorić, A., Lončarević, I. (2016). Školski uspjeh i mentalno zdravlje: Od relacija do intervencija. Napredak: Časopis za interdisciplinarna istraživanja u odgoju i obrazovanju, 157 (3), 302-324. 
95. Wendt, S., Hipps, J., Abrams, A. (2015). Practicing Transcendental Meditation in High Schools: Relationship to Well-being and Academic Achievement Among Students. Contemporary School Psychology, 19 (4), 312-319.

96. Wenig, M. (2003). Yoga kids: The whole-child program of learning through yoga. New York: Stewart, Tabori \& Chang.

97. White, L. S. (2012). Reducing stress in school-age girls through mindful yoga. Journal of Pediatric Healthcare, 26, 45-56.

Internet sources

1. RYE UK - Research on Yoga in Education http://www.ryeuk.org/ (1/3/2021) 


\section{ULOGA JOGE U OBRAZOVANJU}

\section{SAŽETAK}

Cij rada je kroz prikaz istraživanja obrazložiti mogućnosti primjene joge u obrazovanju. Joga uključuje razne tehnike kojima je jedan od ciljeva postizanje psihosocijalne ravnoteže. Svjedoci smo porasta stresa i emocionalnih poremećaja kod djece; djeca se sve manje kreću, a sve su više zaokupljena mnoštvom podražaja koja dolaze neprestano mobitelom, računalom, televizijom. Pregledom niza istraživanja učinaka joge možemo zaključiti da se pokazala učinkovitom kod različitih stanja $i$ bolesti. Vježbanje joge može pomoći u smanjenju stresa, simptoma anksioznosti, depresivnosti. Istražuju se mogućnosti joge kao dijela školskoga kurikuluma, kako za tipičnu tako i za djecu s teškoćama. Dosadašnji rezultati pokazuju moguće prinose joge u školama u vidu poticanja pažnje, samoregulacije te smanjenja napetosti.

Ključne riječi: joga, obrazovanje, škola, zdravlje. 